\title{
Pengaruh Penambahan Sargassum sp. dan Inositol dalam Pakan terhadap Pertumbuhan dan Daya Tahan Juvenil Ikan Gurami (Osphronemus gouramy Lac.)
}

\author{
Dwi Lestari, E. L. Widiastuti*), N. Nurcahyani, dan G. N. Susanto \\ Jurusan Biologi, FMIPA, Universitas Lampung, Bandar Lampung 35145
}

Diterima 08-07-2016 Disetujui 22-12-2016

\begin{abstract}
Gourami (Osphronemus gouramy Lac.) as one of the freshwater fishes, are easily to be cultured but slow in growth rate. One of the ways to enhance their growth rate is by feeding them with high nutritious food. Sargassum sp. and inositol are known compound able to stimulate the growth of some fishes. The study was conducted to determine the effect of Sargassum sp and inositol on commercial feed to the growth rate and survival of juvenile gouramy. The study was conducted from January to April 2015 in Aquatic Laboratory of Biology Department - University of Lampung. Completely randomized designed was used with 4 treatment groups and 5 replications. Anova and Tukey at 5\% levels were applied to this study. The result indicated that addition of inositol and Sargassum sp on commercial food significantly affected the gouramy growth parameters such as the body weight, body length, body width as well as juvenile gouramy spesific growth rate and their survival rate.
\end{abstract}

Keywords: Sargassum sp, inositol, juvenile gouramy growth

\begin{abstract}
ABSTRAK
Ikan gurami (Osphronemus gouramy Lac.) merupakan salah satu ikan air tawar yang pemeliharaannya relatif mudah namun memiliki pertumbuhan yang sangat lambat. Salah satu cara untuk memacu pertumbuhan ikan gurami yaitu dengan pemberian pakan yang bernutrisi tinggi. Sargassum sp. dan inositol diketahui memiliki kandungan senyawa yang dapat memacu pertumbuhan ikan. Penelitian ini bertujuan untuk mengetahui pengaruh pertambahan Sargassum sp. dan inositol pada pakan komersil terhadap pertumbuhan dan daya tahan tubuh ikan gurami. Penelitian ini dilaksanakan mulai bulan Januari 2015 sampai dengan April 2015 di Laboratorium Perairan Biologi Molekuler Jurusan Biologi Fakultas Matematika Dan Ilmu Pengetahuan Alam Universitas Lampung. Penelitian ini menggunakan Rancangan Acak Lengkap (RAL) dengan empat perlakuan dan lima ulangan. Keseluruhan data dari parameter dianalisis menggunakan Anova dan uji Tukey's $(\alpha=5 \%)$. Hasil penelitian ini menunjukkan bahwa pertambahan senyawa inositol dan Sargassum sp. dalam pakan komersil berpengaruh terhadap pertambahan berat tubuh, panjang tubuh, tinggi tubuh, dan laju pertumbuhan spesifik serta mampu meningkatkan kelulushidupan juvenil ikan gurami.
\end{abstract}

Kata Kunci: Pertumbuhan, inositol, juvenil gurami, Sargassum sp.

\footnotetext{
*Telp: +6289657424866

Email: elwidi@yahoo.com
} 


\section{PENDAHULUAN}

Ikan gurami (Osphronemus gouramy Lac.) memiliki pertumbuhan yang relatif lambat jika dibandingkan dengan ikan air tawar lainnya sehingga memerlukan waktu yang lebih lama pada proses budidaya dan pembenihan. Laju pertumbuhan merupakan faktor yang dapat menentukan keberhasilan usaha, karena pertumbuhan yang lambat menyebabkan biaya produksi yang cukup tinggi, ditambah dengan resiko selama waktu pemeliharaan yang lama sehingga hasil produksi yang didapatkan bisa lebih sedikit (KKP 2010). Salah satu upaya dalam penanggulangan dan pencegahan penyakit adalah melalui peningkatan sistem pertahanan tubuh, yaitu dengan menggunakan imunostimulan, vitamin dan hormon (Johny et al. 2005) serta dengan pemberian pakan berkualitas dalam jumlah yang cukup (Ricky 2008).

Ikan dapat tumbuh dengan baik bila diberi pakan yang berkualitas yaitu pakan yang mengandung semua nutrien yang dibutuhkan oleh ikan untuk bertumbuh. Pakan yang berkualitas diperoleh dari hasil ramuan yang baik dari bahan-bahan berkualitas (Palinggi \& Rusman 2005). Salah satu bahan yang dapat menjadi pakan adalah makrolaga seperti Sargassum sp dan senyawa pembentuk membrane sel, yaitu inositol.

Sargassum sp. memiliki kandungan nutrisi tinggi. Sargassum sp. merupakan alga coklat (Phaeophyceae) yang dikenal mengandung bahan kimia utama sebagai sumber alginat, protein, vitamin C, tannin, iodin, dan phenol (Bahar 2012). Sargassum sp. juga diketahui dapat meningkatkan haemosit dalam tubuh dan aktivitas fagositosis, sehingga dapat meningkatkan daya tahan tubuh ikan (Ridlo \& Pramesti 2009). Inositol merupakan nutrisi alami yang tersusun atas isomer gula alkohol dengan rantai C6 dan termasuk kelompok vitamin B-kompleks. Inositol yang lebih dikenal dengan myo-inositol merupakan senyawa karbon yang memiliki berbagai fungsi biologis, diantaranya sebagai sinyal transduksi untuk insulin. Insulin sendiri merupakan hormone yang memiliki peran di dalam pertumbuhan.

Selain itu, daya tahan hewan secara alami tergantung pada stabilitas membran sel. Dengan demikian jika Sargassum sp dan inositol ditambahkan pada pakan komersil serta mampu dimanfaatkan oleh tubuh ikan, maka diharapkan senyawa-senyawa tersebut mampu mempertahankan stabilitas membran sehingga mampu meningkatkan pertahanan tubuh yang selanjutnya mampu meningkatkan pertumbuhan serta kelulushidupan juvenil gurami. Tujuan dari penelitian ini adalah untuk mengetahui pengaruh pertambahan Sargassum sp. dan inositol pada pakan komersil terhadap pertumbuhan dan daya tahan tubuh ikan gurami.

\section{BAHAN DAN METODE}

Penelitian ini menggunakan Rancangan Acak Lengkap (RAL) dengan empat perlakuan yang masingmasing mempunyai lima ulangan yang terdiri dari 1) pakan komersil berupa pelet (kontrol); 2) pakan komersil berupa pelet dengan inositol 10mg/100g pakan; 3) pakan pelet dengan Sargassum sp. 10g/100g pakan; 4) pakan pelet dengan Sargassum sp. 10g/100g pakan ditambah inositol $10 \mathrm{mg} / 100 \mathrm{~g}$ pakan.

Hewan uji yang digunakan adalah juvenil ikan gurami berjumlah 40 ekor dengan panjang 7- $9 \mathrm{~cm}$. Ikan uji dimasukkan pada tiap akuarium dengan ukuran 40 x 30 x 40 $\mathrm{cm}$, dan setiap akuarium berisi 2 ekor Setiap akuarium diberi aerator. Selanjutnya ikan-ikan tersebut dipelihara selama 7 minggu dengan pemberian pakan berupa pelet yang sudah diberi campuran dengan tingkat pemberian pakan sebesar $2 \%$ perhari dari bobot biomassa ikan. Pemberian pakan dilakukan sebanyak 2 kali dalam sehari yaitu pagi hari (pukul 07.00 WIB) dan sore hari (pukul 16.00 WIB).

Parameter penelitian ini adalah pertambahan berat tubuh, yang diukur dengan menggunakan neraca digital, panjang dan tinggi tubuh diukur menggunakan jangka sorong, laju pertumbuhan harian (Spesific Growth Rate / SGR), rasio konversi pakan, sintasan, dan kualitas air. Kualitas air yang diukur adalah suhu diukur menggunakan termometer dan derajat keasaman diukur menggunakan $\mathrm{pH}$ stick. Untuk mencegah penumpukkan ammonia, sifon dilakukan setiap 2 hari sekali, yaitu pada pukul 07.00 (sebelum pemberian pakan pagi). Pada penelitian ini, sebelum perlakuan diberikan, ikan yang digunakan telah mengalami aklimatisasi pada kondisi laboratorium perairan Biologi Moekuler, Jurusan Biologi, FMIPA Universitas Lampung. Untuk tingkat kelulushidupan mencapai 100\% untuk setiap perlakuan, artinya pada penelitian ini tidak ada ikan yang mati. 
Laju pertumbuhan harian atau Specific Growth Rate (SGR) merupakan laju pertambahan bobot individu dalam persen dan dinyatakan dalam persamaan sebagai berikut (Mundheim et al. 2004):

$$
\mathrm{SGR}=\frac{(\mathrm{InWt}-\mathrm{InWo})}{\mathrm{t}} \times 100 \%
$$

Keterangan:

$$
\begin{array}{ll}
\text { SGR } & =\text { Laju pertumbuhan spesifik }(\%) \\
\text { Wo } & =\text { Rata-rata bobot individu pada hari ke- } 0(\mathrm{~g}) \\
\mathrm{Wt} & =\text { Rata-rata bobot individu pada hari ke- } \mathrm{t}(\mathrm{g}) \\
\mathrm{t} & =\text { Lama pemeliharaan (hari) }
\end{array}
$$

Analisis data. Data yang diperoleh dianalisa menggunakan analysis of variance (ANOVA) pada taraf kepercayaan $95 \%$. Jika ada perbedaan nyata $(\mathrm{P}<0,05)$ maka dilanjutkan dengan uji Tukey dengan taraf kepercayaan 95\% untuk mengetahui dimanakah letak signifikasi data. Uji ANOVAdan uji Tukey dilakukan menggunakan aplikasi SPSS.

\section{HASIL DAN PEMBAHASAN}

Selama penelitian ini berlangsung, tidak ada seekor ikanpun yang mengalami kematian. Untuk itu data mengenai kelulushidupan untuk setiap perlakuan adalah $100 \%$. Berikut adalah pertambahan berat tubuh juvenil gurami selama 7 minggu pengamatan Table 1).

Pada Tabel 1, terlihat bahwa pertambahan berat tubuh juvenil ikan gurami pada kontrol mulai terlihat berbeda nyata dengan 3 perlakuan yaitu yang diberi pertambahan inositol, Sargassum sp., dan campuran keduanya (Sargassum sp. dan inositol) pada minggu ke-3 hingga minggu ke-7. Secara umum perlakuan yang diberi pertambahan inositol jika dibandingkan dengan perlakuan yang diberi pertambahan Sargassum sp. diperoleh hasil yang tidak berbeda nyata, namun jika keduanya ditambahkan pada pakan, kelompok ini memberikan peningkatan pertumbuhan yang lebih tinggi dibandingkan dengan ke 3 perlakuan lainnya.

Salah satu mineral yang mempunyai peranan penting dalam pertumbuhan adalah fosfor. Fosfor sendiri terkandung dalam Sargassum sp. Fosfor memegang peranan penting dalam proses kontraksi otot, pembentukkan tulang, dan pembentukkan fosfat yang diperlukan dalam transformasi energi (Stickney 1979). Dengan demikian, ketersedian energi diduga mampu meningkatkan aktivitas tubuh di antaranya adalah serapan nutrisi dari pakan.

Inositol merupakan salah satu senyawa biomolekul yang diperlukan untuk pertumbuhan normal tubuh, pemeliharaan, serta reproduksi. Gejala kekurangan inositol pada beberapa ikan di antaranya berkurangnya nafsu makan, lambatnya pengosongan lambung, anemia, dan pertumbuhan menjadi lambat (NRC 1993). Dengan

\begin{tabular}{|c|c|c|c|c|}
\hline \multirow{2}{*}{$\begin{array}{l}\text { Perlakuan } \\
\text { minggu ke- }\end{array}$} & \multicolumn{4}{|c|}{$\begin{array}{l}\text { Rata-rata pertambahan berat tubuh juvenil ikan gurami selama } 7 \text { minggu Perlakuan } \\
\qquad(\mathrm{X} \pm \mathrm{SEM})(\mathrm{g})\end{array}$} \\
\hline & Kontrol & Inositol & Sargassum sp. & Sargassum sp. + inositol \\
\hline 1 & $1,37 \pm 0,76^{\mathrm{a}}$ & $0,95 \pm 0,21^{\mathrm{a}}$ & $0,98 \pm 0,28^{\mathrm{a}}$ & $1,56 \pm 0,53^{\mathrm{a}}$ \\
\hline 2 & $2,22 \pm 0,33^{\mathrm{a}}$ & $2,53 \pm 0,14^{\mathrm{ab}}$ & $2,56 \pm 0,18^{a b}$ & $3,53 \pm 0,50^{\mathrm{b}}$ \\
\hline 3 & $3,35 \pm 0,34^{a}$ & $4,95 \pm 0,18^{\mathrm{b}}$ & $4,94 \pm 0,33^{\mathrm{b}}$ & $6,74 \pm 0,52^{\mathrm{c}}$ \\
\hline 4 & $4,71 \pm 0,35^{\mathrm{a}}$ & $7,80 \pm 0,27^{\mathrm{b}}$ & $7,59 \pm 0,52^{\mathrm{b}}$ & $10,21 \pm 0,45^{\mathrm{c}}$ \\
\hline 5 & $6,12 \pm 0,31^{\mathrm{a}}$ & $10,76 \pm 0,44^{\mathrm{b}}$ & $10,46 \pm 0,65^{\mathrm{b}}$ & $13,54 \pm 0,42^{\mathrm{c}}$ \\
\hline 6 & $7,47 \pm 0,28^{\mathrm{a}}$ & $13,84 \pm 0,57^{\mathrm{b}}$ & $13,20 \pm 0,61^{\mathrm{b}}$ & $17,25 \pm 0,29^{c}$ \\
\hline 7 & $8,76 \pm 0,33^{a}$ & $16,78 \pm 0,56^{\mathrm{b}}$ & $16,01 \pm 0,56^{\mathrm{b}}$ & $20,83 \pm 0,21^{\mathrm{c}}$ \\
\hline
\end{tabular}
demikian, inositol pada pakan ini diduga memiliki kualitas pakan yang baik sehingga mampu meningkatkan nafsu makan dan serapan nutrisi juvenil ikan gurami.

Tabel 1 Pertambahan berat tubuh juvenil ikan gurami selama 7 minggu

Keterangan : $\mathrm{X} \pm \mathrm{SEM}$ : Nilai rata-rata pertambahan berat tubuh \pm galat baku.

Penggunaan huruf superscript yang tidak sama pada baris yang sama menandakan adanya perbedaan yang nyata antar perlakuan pada uji Tukey dengan taraf signifikansi $(\alpha) 5 \%$ 
Rata-rata pertambahan panjang tubuh juvenil ikan gurami selama 7 minggu dapat dilihat pada Tabel 2. Secara umum pada kelompok perlakuan yang diberi pertambahan campuran (Sargassum sp. + inositol) selama 7 minggu menunjukkan hasil rata-rata pertambahan panjang yang lebih tinggi dibandingkan dengan kontrol dan 2 perlakuan lainnya. Dengan demikian, diduga bahwa pertambahan campuran (Sargassum sp. + inositol) yang meningkatkan pertambahan berat tubuh berkontribusi terhadap pertambahan panjang tubuh ikan gurami.

Dengan demikian diduga dapat dikatakan bahwa berat dan panjang memberikan hubungan yang searah, yaitu saat berat juvenil ikan gurami meningkat maka proses pemanjangan tubuh juga akan meningkat. Juvenil ikan gurami (Ospronemus gouramy Lac.) dapat menjadi lebih berat dan menunjukkan hubungan yang positif terhadap panjang merupakan tanda dari pertumbuhan.

Selanjutnya untuk pertambahan tinggi tubuh juvenil ikan gurami selama 7 minggu pengamatan dapat dilihat pada Tabel 3. Pada table tersebut terlihat bahwa rata-rata pertambahan tinggi tubuh juvenil ikan gurami (Osphronemus gouramy Lac.) pada kelompok perlakuan kontrol menunjukkan hasil tidak berbeda nyata dengan 3 perlakuan lainnya pada minggu ke-1 hingga minggu ke-3. Sedangkan pada kontrol menunjukkan hasil yang berbeda nyata dengan perlakuan pertambahan inositol dan perlakuan pertambahan campuran (Sargassum sp. + inositol) pada minggu ke-6 hingga minggu ke-7. Rata-rata pertambahan tinggi tubuh juvenil ikan pada 3 perlakuan yaitu yang diberi pertambahan inositol, Sargassum sp.,

Tabel 2 Pertambahan panjang tubuh juvenil ikan gurami selama 7 minggu

\begin{tabular}{|c|c|c|c|c|}
\hline \multirow[t]{2}{*}{$\begin{array}{l}\text { Perlakuan } \\
\text { minggu ke- }\end{array}$} & \multicolumn{4}{|c|}{$\begin{array}{l}\text { Rata-rata pertambahan panjang tubuh juvenil ikan gurami selama } 7 \text { minggu Perlakuan } \\
\qquad(\mathrm{X} \pm \mathrm{SEM})(\mathrm{cm})\end{array}$} \\
\hline & Kontrol & Inositol & Sargassum sp. & Sargassum sp. + inositol \\
\hline 1 & $0,07 \pm 0,01^{a}$ & $0,16 \pm 0,14^{b}$ & $0,15 \pm 0,01^{\mathrm{b}}$ & $0,20 \pm 0,02^{b}$ \\
\hline 2 & $0,18 \pm 0,03^{a}$ & $0,34 \pm 0,01^{\mathrm{b}}$ & $0,32 \pm 0,01^{\mathrm{ab}}$ & $0,46 \pm 0,07$ b \\
\hline 3 & $0,34 \pm 0,03^{a}$ & $0,56 \pm 0,02^{\mathrm{bc}}$ & $0,53 \pm 0,02^{\mathrm{b}}$ & $0,68 \pm 0,06^{c}$ \\
\hline 4 & $0,52 \pm 0,03^{a}$ & $0,77 \pm 0,03^{\text {bc }}$ & $0,76 \pm 0,04^{b}$ & $0,94 \pm 0,06^{c}$ \\
\hline 5 & $0,65 \pm 0,04$ & $0,97 \pm 0,03^{\mathrm{b}}$ & $0,94 \pm 0,03^{\mathrm{b}}$ & $1,30 \pm 0,12^{\mathrm{c}}$ \\
\hline 6 & $0,78 \pm 0,05^{\mathrm{a}}$ & $1,16 \pm 0,03^{\mathrm{b}}$ & $1,10 \pm 0,02^{b}$ & $1,54 \pm 0,10^{c}$ \\
\hline 7 & $0,90 \pm 0,05^{\mathrm{a}}$ & $1,36 \pm 0,05^{\mathrm{b}}$ & $1,32 \pm 0,03^{b}$ & $1,86 \pm 0,11^{\mathrm{c}}$ \\
\hline
\end{tabular}

Keterangan : $\mathrm{X} \pm$ SEM : Nilai rata-rata pertambahan panjang tubuh \pm galat baku.

Penggunaan huruf superscript yang tidak sama pada baris yang sama menandakan adanya perbedaan yang nyata antar perlakuan pada uji Tukey dengan taraf signifikansi $(\alpha) 5 \%$

Tabel 3 Pertambahan tinggi tubuh juvenil ikan gurami selama 7 minggu

Perlakuan Rata-rata pertambahan tinggi tubuh juvenil ikan gurami selama 7 minggu perlakuan minggu ke- $\quad(X \pm$ SEM) $(\mathrm{cm})$

\begin{tabular}{ccccc}
\hline & Kontrol & Inositol & Sargassumsp. & Sargassum sp. + inositol \\
\hline 1 & $0,02 \pm 0,00^{\mathrm{a}}$ & $0,03 \pm 0,00^{\mathrm{a}}$ & $0,02 \pm 0,00^{\mathrm{a}}$ & $0,03 \pm 0,00^{\mathrm{a}}$ \\
2 & $0,04 \pm 0,01^{\mathrm{a}}$ & $0,06 \pm 0,01^{\mathrm{a}}$ & $0,05 \pm 0,01^{\mathrm{a}}$ & $0,07 \pm 0,01^{\mathrm{a}}$ \\
3 & $0,07 \pm 0,01^{\mathrm{a}}$ & $0,09 \pm 0,01^{\mathrm{a}}$ & $0,08 \pm 0,01^{\mathrm{a}}$ & $0,10 \pm 0,01^{\mathrm{a}^{\mathrm{a}}}$ \\
4 & $0,09 \pm 0,01^{\mathrm{a}}$ & $0,13 \pm 0,01^{\mathrm{ab}}$ & $0,11 \pm 0,01^{\mathrm{ab}}$ & $0,14 \pm 0,01^{\mathrm{b}}$ \\
5 & $0,12 \pm 0,01^{\mathrm{a}}$ & $0,17 \pm 0,01^{\mathrm{ab}}$ & $0,14 \pm 0,01^{\mathrm{ab}}$ & $0,18 \pm 0,01^{\mathrm{b}}$ \\
6 & $0,15 \pm 0,01^{\mathrm{a}}$ & $0,21 \pm 0,01^{\mathrm{b}}$ & $0,18 \pm 0,01^{\mathrm{ab}}$ & $0,22 \pm 0,02^{\mathrm{b}}$ \\
7 & $0,17 \pm 0,01^{\mathrm{a}}$ & $0,24 \pm 0,02^{\mathrm{b}}$ & $0,21 \pm 0,02^{\mathrm{ab}}$ & $0,26 \pm 0,02^{\mathrm{b}}$ \\
\hline
\end{tabular}

Keterangan : $\mathrm{X} \pm$ SEM : Nilai rata-rata pertambahan tinggi tubuh \pm galat baku

Penggunaan huruf superscript yang tidak sama pada baris yang sama menandakan adanya perbedaan yang nyata antar perlakuan pada uji Tukey dengan taraf signifikansi $(\alpha) 5 \%$ 
dan campuran keduanya Sargassum sp. dengan inositol menunjukkan hasil yang lebih tinggi dibandingkan dengan kontrol.

Laju pertumbuhan ikan gurami sangat diperlukan dalam usaha budidaya. Hasil penelitian ini menunjukkan adanya pengaruh secara signifikan dari pemberian pakan dengan pertambahan inositol, Sargassum sp., dan campuran (Sargassum sp. + inositol) terhadap laju pertumbuhan spesifik juvenil ikan gurami. Selanjutnya untuk mengetahui tingkat perbedaan antar perlakuan terhadaplaju pertumbuhan spesifik (SGR) dapat dilihat pada Tabel 4.

Tabel 4 menunjukkan bahwa rata-rata laju pertumbuhan spesifik terbaik terdapat pada perlakuan yang diberi pertambahan campuran (Sargassum sp. + inositol) sebesar 1,924\%/hari pada minggu ke-3. Walaupun demikian, perlakuan yang diberi pertambahan campuran (Sargassum sp. dan inositol) tidak berbeda nyata dengan perlakuan pemberian pakan dengan pertambahan inositol dan perlakuan yang diberi pertambahan Sargassum sp.

Rata-rata laju pertumbuhan spesifik pada perlakuan kontrol memberikan hasil yang terendah sepanjang penelitian ini berlangsung (7 minggu) serta berbeda nyata dengan ke-3 perlakuan lainnya, yaitu perlakuan dengan pertambahan inositol, Sargassum sp., dan campuran (Sargassum sp. + inositol). Hal ini menunjukkan bahwa pemberian pakan dengan 4 perlakuan di atas berpengaruh secara signifikan terhadap laju pertumbuhan spesifik juvenil ikan gurami.
Selanjutnya untuk mengetahui seberapa besar efisiensi pakan pada pertumbuhan juvenile gurami, maka rasio konservesi pakan ditentukan. Rata-rata ratio konversi pakan juvenil ikan gurami dapat dilihat pada Tabel 5. Ratio konversi pakan pun menunjukkan perbedaan yang signifikan pada taraf $5 \%$ untuk semua perlakuan dibandingkan dengan kontrol. Ratio konversi pakan terbaik terdapat pada perlakuan pertambahan campuran (Sargassum sp. + inositol) yaitu sebesar 1,645 pada minggu ke-3 yang menunjukkan tingkat efisiensi pakan terbaik.

Pada Tabel 5 terlihat bahwa pemberian inositol dan Sargassum sp serta keduanya dalam pakan komersil memberikan efisiensi pakan yang cukup baik, dan jauh lebih efisien jika dibandingkan dengan perlakuan/kelompok control, khususnya setelah minggu pertama. Rasio konsversi pakan untuk perlakuan control mencapai hampir dua kali lipat jika dibandingkan dengan perlakuan lainnya. Walau demikian nilai ratio konversi pakan untuk semua perlakuan masih berada pada kisaran konversi pakan yang baik, yaitu berkisar antara 1,5- 8 (Huet 1997). Dengan demikian, diduga bahwa pertambahan inositol, Sargasum sp.,dan campuran keduanya meningkatkan kualitas dari pakan yang digunakan, sehingga meningkatkan pertumbuhan.

Tingkat kelulushidupan juvenil ikan gurami pada penelitian ini, diketahui bahwa pada perlakuan kontrol dan pertambahan inositol tidak mencapai $100 \%$ yaitu 80 dan $90 \%$, sedangkan tingkat kelulushidupan pada 2 perlakuan lainnya dapat mencapai $100 \%$.

Tabel 4 Laju pertumbuhan spesifik (SGR) juvenil ikan gurami selama 7 minggu

\begin{tabular}{|c|c|c|c|c|}
\hline \multirow[t]{2}{*}{$\begin{array}{l}\text { Perlakuan } \\
\text { minggu ke- }\end{array}$} & \multicolumn{4}{|c|}{$\begin{array}{l}\text { Rata-Rata SGR Juvenil Ikan Gurami Selama } 7 \text { Minggu Perlakuan } \\
\qquad(X \pm S E M)(\%)\end{array}$} \\
\hline & Kontrol & Inositol & Sargassum sp. & Sargassum sp. + inositol \\
\hline 1 & $1,07 \pm 0,27 \mathrm{a}$ & $0,74 \pm 0,08^{a}$ & $0,77 \pm 0,099^{a}$ & $1,12 \pm 0,16^{a}$ \\
\hline 2 & $0,64 \pm 0,10^{a}$ & $1,14 \pm 0,07^{\mathrm{b}}$ & $1,17 \pm 0,11^{\mathrm{b}}$ & $1,30 \pm 0,15^{\mathrm{b}}$ \\
\hline 3 & $0,82 \pm 0,13^{\mathrm{a}}$ & $1,59 \pm 0,15^{\mathrm{b}}$ & $1,60 \pm 0,18^{\mathrm{b}}$ & $1,92 \pm 0,06^{b}$ \\
\hline 4 & $0,91 \pm 0,08^{\mathrm{a}}$ & $1,67 \pm 0,08^{\mathrm{b}}$ & $1,60 \pm 0,13^{\mathrm{b}}$ & $1,82 \pm 0,10^{\mathrm{b}}$ \\
\hline 5 & $0,89 \pm 0,08^{a}$ & $1,54 \pm 0,09^{b}$ & $1,53 \pm 0,07^{\mathrm{b}}$ & $1,56 \pm 0,13^{\mathrm{b}}$ \\
\hline 6 & $0,79 \pm 0,04^{a}$ & $1,45 \pm 0,07^{\mathrm{b}}$ & $1,33 \pm 0,07^{\mathrm{b}}$ & $1,56 \pm 0,11^{\mathrm{b}}$ \\
\hline 7 & $0,71 \pm 0,09^{a}$ & $1,26 \pm 0,03^{\mathrm{b}}$ & $1,25 \pm 0,06^{\mathrm{b}}$ & $1,36 \pm 0,07^{\mathrm{b}}$ \\
\hline
\end{tabular}

Keterangan : $\mathrm{X} \pm \mathrm{SEM}$ : Nilai rata-rata $\mathrm{SGR} \pm$ galat baku

Penggunaan huruf superscript yang tidak sama pada baris yang sama menandakan adanya perbedaan yang nyata antar perlakuan pada uji Tukey dengan taraf signifikansi $(\alpha) 5 \%$ 
Tabel 5 Ratio konversi pakan (FCR) juvenil ikan gurami selama 7 minggu

\begin{tabular}{ccccc}
\hline \multirow{2}{*}{$\begin{array}{c}\text { Perlakuan } \\
\text { minggu ke- }\end{array}$} & \multicolumn{4}{c}{$\begin{array}{c}\text { Rata-Rata FCR Juvenil Ikan Gurami Selama 7 Minggu Perlakuan } \\
(\mathrm{X} \pm \text { SEM) }(\mathrm{cm})\end{array}$} \\
\cline { 2 - 5 } & Kontrol & Inositol & Sargassumsp. & Sargassum sp. + inositol \\
\hline 1 & $3,68 \pm 1,08^{\mathrm{a}}$ & $4,57 \pm 0,35^{\mathrm{a}}$ & $4,51 \pm 0,50^{\mathrm{a}}$ & $3,44 \pm 0,93^{\mathrm{a}}$ \\
2 & $5,90 \pm 1,13^{\mathrm{a}}$ & $2,84 \pm 0,15^{\mathrm{b}}$ & $2,81 \pm 0,18^{\mathrm{a}}$ & $2,71 \pm 0,50^{\mathrm{b}}$ \\
3 & $4,66 \pm 0,88^{\mathrm{a}}$ & $2,05 \pm 0,20^{\mathrm{b}}$ & $2,09 \pm 0,18^{\mathrm{b}}$ & $1,65 \pm 0,02^{\mathrm{b}}$ \\
4 & $3,72 \pm 0,21^{\mathrm{a}}$ & $1,91 \pm 0,10^{\mathrm{b}}$ & $1,98 \pm 0,14^{\mathrm{b}}$ & $1,67 \pm 0,05^{\mathrm{b}}$ \\
5 & $3,78 \pm 0,31^{\mathrm{a}}$ & $1,99 \pm 0,12^{\mathrm{b}}$ & $2,01 \pm 0,08^{\mathrm{b}}$ & $1,90 \pm 0,15^{\mathrm{b}}$ \\
6 & $3,98 \pm 0,21^{\mathrm{a}}$ & $2,04 \pm 0,10^{\mathrm{b}}$ & $2,16 \pm 0,12^{\mathrm{b}}$ & $1,81 \pm 0,15^{\mathrm{b}}$ \\
7 & $3,96 \pm 0,56^{\mathrm{a}}$ & $2,12 \pm 0,14^{\mathrm{b}}$ & $2,27 \pm 0,12^{\mathrm{b}}$ & $1,94 \pm 0,17^{\mathrm{b}}$ \\
\hline
\end{tabular}

Keterangan : $\mathrm{X} \pm$ SEM : Nilai rata-rata ratio konversi pakan \pm galat baku

Penggunaan huruf superscript yang tidak sama pada baris yang sama menandakan adanya perbedaan yang nyata antar perlakuan pada uji Tukey dengan taraf signifikansi $(\alpha) 5 \%$

Perlakuan yang diberi pertambahan Sargassum sp., dan campuran (Sargassum sp. + inositol) memiliki kandungan nutrisi yang seimbang, sehingga dapat memenuhi kebutuhan kalori dalam proses metabolisme, pertumbuhan, dan meningkatkan daya tahan tubuh untuk bertahan hidup. Hal ini diduga inositol dan Sargassum sp. juga dapat meningkatkan daya tahan tubuh juvenil ikan gurami.

Parameter penunjang dari penelitian ini adalah parameter kualitas air. Kualitas air menentukan keberhasilan dari upaya budidaya perikanan. Air sebagai media hidup ikan yang dipelihara harus memeuhi persyaratan baik kualitas maupun kuantitasnya Ghufron (2009). Firdaus (2004) menyatakan bahwa suhu lingkungan yang tinggi tetapi masih dalam batas toleransi ikan, dapat meningkatkan reaksi antibodi apabila diserang mikroorganisme patogen. Dalam penelitian ini parameter kualitas air yang diukur adalah suhu dan derajat keasaman $(\mathrm{pH})$. Pengukuran kualitas air dalam ruangan selama penelitian secara umum menunjukkan keadaan lingkungan yang baik bagi kehidupan juvenil ikan gurami yaitu dengan suhu $24-27^{\circ} \mathrm{C}$ dan $\mathrm{pH} 7$, masih berada dalam kisaran yang dinyatakan oleh Ghufron (2009), yang mengatakan Ikan gurame akan tumbuh baik pada lingkungan dengan suhu air sekitar $24-28^{\circ} \mathrm{C}$ dan $\mathrm{pH} 6,5-8$.

\section{SIMPULAN}

Penambahan senyawa inositol dan Sargassum sp. Pada pakan komersil mampu meningkatkan pertambahan berat tubuh, panjang tubuh, tinggi tubuh, dan laju pertumbuhan spesifik pada juvenil ikan gurami (Osphronemus gouramy Lac.). Pertambahan senyawa inositol dan Sargassum sp. dalam pakan komersil juga mampu menurunkan rasio konversi pakan pada juvenile gurami.

\section{UCAPAN TERIMA KASIH}

Penulis mengucapkan terima kasih kepada Endang Linirin Widiastuti Ph.D. sebagaidosen pembimbing utama yang mendanai penelitian ini sert Dra. Nuning Nurcahyani M.Sc. dan Bapak Dr. G. Nugroho Susanto, M.Sc. sebagai dosen pembimbing yang telah meluangkan waktu untuk memberikan saran dan masukan untuk kesempurnaan jurnal ini.

\section{DAFTAR PUSTAKA}

Bahar, R. 2005. Ekstraksi Alginat dari Rumput Laut Sargassum sp. dan Aplikasinya Sebagai Pengawet Buah. Makassar.Jurnal Marina Chimica Acta 13: 1620.

Firdaus. 2004. Pengaruh Vitamin C dalam Percobaan Imunoprofilaksi Terhadap Infeksi Bakteri Streptococcusiniae pada Ikan Nila (Oreochromis niloticus). Bogor: Institut Pertanian Bogor.

Haryati,A.M. 2005. Makanan Ikan. Fish Fisheries Project Malang. UNIBRAW. Malang.

Huet, M. 1997. Textbook of Fish Culture : Breeding and Cultivation of Fish. $2^{\text {nd }}$ Ed. Fishing News Book. Ltd. England. 436 halaman.

Johny, Roza F., Mahardika D.K., Zafran \& PrijonoA. 2005. Penggunaan Immunostimulan Untuk Meningkatkan 
Kekebalan Nonspesifik Benih Ikan kerapu Lumpur, Epinephelus coiodesTerhadap infeksi Virus irido. Jurnal PenelitianPerikanan Indonesia XI(5): 75-83.

Kementerian Kelautan dan Perikanan (KKP). 2010. Indonesian Fisheries Statistics Index 2009. Jakarta: Kementerian Kelautan dan Perikanan.

Ghufron, M.H.K. 2009. Pengelolaan Kualitas Air dalam Budidaya Perairan. Jakarta: PT Rineka Cipta. 210 halaman.

Mundheim, H., Aksnes A \& Hope B. 2004. Growth, feed efficiency and digestibility in salmon (Salmo salar L.) fed different dietary proportions of vegetable protein sources in combination with two fish meal qualities. Journal Aquaculture 237: 315-331.
NRC. 1993. Nutrient Requirement of Fish. National Academy of Science. USA:National Press.Pp 39-53.

Palinggi \&Usman. 2005. Manajemen Pemberian Pakan. Balai Riset Perikanan Budidaya Air Payau. Maros.

Ricky, B. 2008. Usaha Pembenihan Gurami (Osphronemus gouramy). Jakarta: Penebar Swadaya.

Ridlo, A \& Pramesti R. 2009. Aplikasi Ekstrak Rumput Laut Sebagai Agen Imunostimulan Sistem Pertahanan Non Spesifik pada Udang (L. vannamei).Semarang. Jurnal Perikanan Vol. 14(3): 133-137.

Stickney, R.R. 1979. Principles of Warm Water Aquaculture. John Wiley and Sons Inc. New York. Pp 223-229. 